International Research Journal of Management, IT \& Social Sciences
Available online at https://sloap.org/journals/index.php/irjmis/
Vol. 6 No. 3, May 2019, pages: 108 116
ISSN: 2395-7492
https://doi.org/10.21744/irjmis.v6n3.643

\title{
Free Cash Flow Effect towards Firm Value
}

\author{
Ida Ayu Made Chandra Dewi ${ }^{a}$ \\ Maria Mediatrix Ratna Sari ${ }^{b}$ \\ I.G.A.N Budiasih ${ }^{\mathrm{c}}$ \\ Herkulanus Bambang Suprasto ${ }^{d}$
}

Article history:

Received: 27 December 2018

Accepted: 31 March 2019

Published: 31 May 2019

\section{Keywords:}

dividend payout;

firm value;

free cash flow;

investment opportunity set;

main board stock index;

\begin{abstract}
A company is established to raise the value of the firm by maximizing profit and shareholder's wealth. In the capital market, firm value is reflected in the stock price. To raise a firm value, needed to investigate the determinant of firm value. So, this research is aimed to determine the effect of free cash flow on firm value with dividend payout and investment opportunity set as mediator. Population in this research was companies listed on the Main Board Stock Index in Indonesian Stock Exchange for 2013-2017. The sample is 189 observation and it was taken by using purposive sampling technique. Data analysis technique used in this research is path analysis and Sobel test. This research founded that free cash flow has a positive significant effect on firm value and dividend payout, free cash flow has a negative effect on investment opportunity set, dividend payout has a positive significant effect on firm value, and investment opportunity set has a positive significant effect on firm value. Furthermore, dividend payout act as a mediator on the effect of free cash flow on firm value, but investment opportunity unable to mediate the effect of free cash flow on firm value.
\end{abstract}

2395-7492@ Copyright 2019. The Author. This is an open-access article under the CC BY-SA license (https://creativecommons.org/licenses/by-sa/4.0/) All rights reserved.

\section{Author correspondence: \\ Ida Ayu Made Chandra Dewi, \\ Universitas Udayana, Denpasar, Bali, Indonesia. \\ Email address: iamdchandradewi@gmail.com}

\section{Introduction}

A company is established to raise the value of the firm by maximizing profit and shareholder's wealth. Forgo public company, firm value is the price that investors are willing to pay if the company is sold. The reason is investors need to get high return in investing, so they will choose a company with high value. Kusumajaya (2011), said that "firm value is very important because it reflected how the current performance's company and the prospect of the company

\footnotetext{
${ }^{\text {a }}$ Universitas Udayana, Denpasar, Indonesia

${ }^{\mathrm{b}}$ Universitas Udayana, Denpasar, Indonesia

${ }^{c}$ Universitas Udayana, Denpasar, Indonesia

${ }^{\mathrm{d}}$ Universitas Udayana, Denpasar, Indonesia
} 
in the future". In the capital market, the value of a firm is reflected in the price of the company's stock. In 2013-2017, the firm value that listed on the Main Board Stock Index on IDX showed fluctuations, which means that many factors influence the firm value. Brigham et al., (2016), said that "fundamentally, the firm value depends on the expected free cash flow".

Free cash flow is excess cash in a company that shows the level of financial flexibility of the company. It can be a positive signal about the company's performance. When free cash flow is high, the ability of the company to increase the shareholder's wealth also high, so the firm value increased. Previous research regarding firm value has been carried out a lot. Hermuningsih (2016); Al-Zararee \& Al-Azzawi (2016); Ghodrati \& Hashemi (2014), and Suartawan \& Yasa (2016), found that free cash flow has a positive effect on firm value, but Naini (2014) and Embara et al., (2012), found that free cash flow didn't have an effect on firm value. This inconsistency becomes base for adding dividend payout and investment opportunity set as a mediator in the relation between free cash flow and firm value. This relation could be explained with agency theory (Ogunsiji \& Ladanu, 2017; Nuryani et al., 2018).

Agency Theory explains that agents and principals have different interests that trigger a conflict of the agency. One source of agency conflict is free cash flow. It is because agents and principals have different interest in making the best choice to use free cash flow. In this situation, management as an agent has to make the right decision regarding it's used whether to be distributed as dividend or will be used to take the existing investment opportunity set.

The dividend is part of a company's net income that distributed to shareholders. The amount of dividends that distributed can increase the wealth of shareholders, so it will lead the increasing of firm value. Previous research regarding the effect of dividend payout on firm value has been carried out by Sedana (2016); Rizqia et al., (2013); Febriana et al., (2016). The result showed dividend payout has a positive effect on firm value. It means the decision to distribute dividend is a positive signal about the liquidity of the company, so that the firm value can increase. Firm value also can be increased when free cash flow is used to take the existing investment opportunity set. Rizqia $e t$ al., (2013) and Suartawan \& Yasa (2016), viewed the investment opportunity set mastering the positive effect regarded the firm value. Due to it shows company growth for the future. Then, the investor will give a positive response to the company.

Based on the background, this study purposes to analyze the effect of free cash flow on the firm value that listed on the Main Board Stock Index on IDX with dividend payout and investment opportunity set as mediator. The company that listed on the Main Board Stock Index chosen in this study, because this index registers the large companies that have good performance records. It can be guaranteed for the investor who wants to invest in IDX.

\section{Literature Review and Hypothesis}

Agency theory describes the relation between agents and principals (Jensen \& Meckling, 1976). The agent is a party who has the assignment to manage the company and take every decision based on the interest of the shareholder. One decision that taken by management is regarding use free cash flow.

Free cash flow shows the financial flexibility of the company to welfare shareholders. The research conducted by Hermuningsih (2016); Al-Zararee \& Al-Azzawi (2016); Ghodrati \& Hashemi (2014); and Suartawan \& Yasa (2016), proved that higher free cash flow reflects a good performance that can be a positive signal for investor regarding company's prospect in future. Based on the description, the hypothesis is proposed as follows:

$\mathrm{H}_{1}$ : Free cash flow has a positive effect on firm value.

Free cash flow is an excess of the company's cash flow that can be used to finance investments and pay a dividend. Jensen (1986) declares that "free cash flow should be distributed as dividend or used to pay debts for avoiding the possibility of investing in a negative net present value". The existence of free cash flow encourages shareholder to ask management to use free cash flow for paying a dividend to improve the shareholder's wealth. Previous research found that free cash flow has a positive effect on dividend policy which is proxied by dividend payout ratio (Mancinelli \& Ozkan, 2006; Kouki \& Guzani, 2009; Rosdini, 2009; Thanatawee, 2011; Lucyanda \& Lilyana, 2012; Arfan \& Maywindlan, 2013; Efni, 2013). Based on the explanation, the hypothesis is proposed as follows:

$\mathrm{H}_{2}$ : Free cash flow has a positive effect on dividend payout.

Suherli \& Harahap (2004), said that "when the company in a good condition, management tends to use free cash flow for taking investment opportunity set to get benefit in the future rather than paying a dividend". When free cash flow is high, the opportunity for management to take investment opportunity set by using free cash flow is getting higher. Based on the explanation, the hypothesis is proposed as follows:

Dewi, I. A. M. C., Sari, M. M. R., Budiasih, I., \& Suprasto, H. B. (2019). Free cash flow effect towards firm value. International Research Journal of Management, IT and Social Sciences, 6(3), 108-116. https://doi.org/10.21744/irjmis.v6n3.643 
$\mathrm{H}_{3}$ : Free cash flow mastering the positive effect regarded the investment opportunity set.

Dividends are part of the company's net income that distributed to shareholders. Based on agency theory, management and shareholders have a different interest related to the distribution of dividends. Management tends to hold profit of the company as retained earnings, meanwhile, shareholders want to be distributed as dividends. Gordon (1963), states that "the distribution of high dividends can increase the firm value". This is consistent with bird in the hand theory, which states that investors prefer returns as a dividend rather than capital gain. Fenandar (2012); Rizqia et al., (2013); Febriana et al., (2016); Sedana (2016); Senata (2016), and Esana \& Darmawan (2017), found that dividend payout has a positive effect on firm value. Based on the explanation, the hypothesis is proposed as follows: $\mathrm{H}_{4}$ : Dividend payout has a positive effect on firm value.

Investment opportunity set is an investment opportunity which is a combination of investment and future investment choices with a positive net present value (Myers, 1977). Myers (1977) and Fama \& French (1998), state that "investment is a very important decision for the company because it is directly related to the company's goal to raise firm value". Previous research on investment opportunity set conducted mastering positive effect on firm value (Rizqia, et al., 2013 and Suartawan \& Yasa, 2016). The hypothesis is proposed as follows:

$\mathrm{H}_{5}$ : Investment opportunity set mastering a positive effect on toward firm value.

Free cash flow is an excess of the company's cash flow that can be used to raise the shareholder's wealth by dividends payout. When the goal of the company to raise the wealth of shareholder is achieved, the firm value will increase. Therefore, when free cash flow is high, the chances of dividend payments will be greater, so the public will give a positive response regarding the company's financial condition. Aftereffect, the firm value will increase. The hypothesis is proposed as follows:

$\mathrm{H}_{6}$ : Dividend payout is able to mediate free cash flow effect toward firm value.

Myers (1977) and Fama \& French (1998), explain that investment is a very important decision that directly related to the goal of the company to raise the firm value. As an agent, management prefers the free cash flow is used to fund existing investment opportunity to get more value added in the future. The hypothesis is proposed as follows:

$\mathrm{H}_{7}$ : Investment opportunity set is able to mediate free cash flow effect toward firm value.

\section{Materials and Methods}

The population in the current study was a company. There was listed on Main Board Stock Index in IDX 20132017 period. The sample is taken by a non probability sampling method and purposive sampling technique. Type of data used in this study is quantitative data and secondary data source. Analysis data technique used in this study is path analysis and Sobel test. The conceptual model of the study can be seen in Figure 1 below.



Figure 1. Research model

\section{Results and Discussions}

Path Analysis

Path analysis is used to analyze the indirect effect of the independent variable on the dependent variable. The path analysis result is showed as follows: 
Table 1

The direct effect of variables

\begin{tabular}{llllll}
\hline & \multicolumn{2}{l}{ Unstandardized Coefficients } & Standardized Coefficients & t & Sig. \\
\hline & B & Std. Error & Beta & & \\
FCF to PBV & 0,970 & 0,201 & 0,372 & 4,823 & 0,000 \\
DPR to PBV & 0,382 & 0,088 & 0,289 & 4,329 & 0,000 \\
IOS to PBV & 1,148 & 0,346 & 0,250 & 3,322 & 0,001 \\
FCF to DPR & 0,441 & 0,141 & 0,224 & 3,139 & 0,002 \\
FCF to IOS & $-0,285$ & 0,036 & $-0,502$ & $-7,927$ & 0,000 \\
\hline
\end{tabular}

Based on Table 1, the structural regression equation and the effect indirectly variable can purpose as follows:

a. Effect of FCF, DPR, and IOS on PBV

$\mathrm{PBV}=0,970 \mathrm{FCF}+0,382 \mathrm{DPR}+1,148 \mathrm{IOS}+\varepsilon_{1}$

b. Effect of FCF on PBV

$\mathrm{DPR}=0,441 \mathrm{FCF}+\varepsilon_{2}$

c. Effect of FCF on IOS

$\mathrm{IOS}=-0,285 \mathrm{FCF}+\varepsilon_{3}$

Informastion:

$\mathrm{PBV}=$ Price to Book Value

$\mathrm{FCF}=$ Free Cash Flow

DPR $=$ Dividend Payout Ratio

IOS = Investment Opportunity Set

Based on Table 1, the result of sobel test can be seen in following table.

Table 2

The indirect effect of variables

\begin{tabular}{clllc}
\hline & Path coefficient & Quadratic Path Coefficient & $\mathrm{S}_{\mathrm{p} 2 \mathrm{p} 4}$ & $t_{1}$ \\
\hline $\mathrm{p}_{2}$ & 0,441 & 0,194481 & 0,067536 & 2,494 \\
$\mathrm{p}_{4}$ & 0,382 & 0,145924 & & \\
$\mathrm{Sp}_{2}$ & 0,141 & 0,019881 & & \\
$\mathrm{Sp}_{4}$ & 0,088 & 0,007744 & & \\
& & & & \\
& Path coefficient & Quadratic Path Coefficient & $\mathrm{S}_{\mathrm{p} 3 \mathrm{p} 5}$ & \\
$\mathrm{p}_{3}$ & $-0,285$ & 0,081225 & 0,107643 & $-3,039$ \\
$\mathrm{p}_{5}$ & 1,148 & 1,317904 & & \\
$\mathrm{Sp}_{3}$ & 0,036 & 0,001296 & & \\
$\mathrm{Sp}_{5}$ & 0,346 & 0,119716 & & \\
\hline
\end{tabular}

Based on Table 2, founded $t_{1}$ is 2,494 and t-table with significance level is 0,05 and degree of freedom ( $d f$ ) 185 is 1,653. It means $t_{1}$ is higher than the $t$-table. Therefore, dividend payout is able to mediate the effect of free cash flow on firm value. Meanwhile, $t_{2}$ is $-3,039$ that smaller than $t$ table, so investment opportunity set is unable to mediate the free cash flow effect regarded the firm value.

\section{Model Validity Check}

The validity of the regression model can be seen from the total coefficient of determinant that shows how the ability of independent variables' variants to explain the variants of the dependent variable. The result can shows as follows:

Dewi, I. A. M. C., Sari, M. M. R., Budiasih, I., \& Suprasto, H. B. (2019). Free cash flow effect towards firm value. International Research Journal of Management, IT and Social Sciences, 6(3), 108-116. https://doi.org/10.21744/irjmis.v6n3.643 
Table 3

R Square

\begin{tabular}{lll}
\hline Dependent Variable & Dependent Variable & R Square \\
\hline PBV & DPR, IOS, FCF & 0,246 \\
DPR & FCF & 0,050 \\
IOS & FCF & 0,252 \\
\hline
\end{tabular}

Based on Table 3, the total coefficient of the determinant is calculated as follows:

$$
\begin{aligned}
& R_{m}^{2}=1-\left\{\left(1-R_{1}^{2}\right)\left(1-R_{2}^{2}\right)\left(1-R_{3}^{2}\right)\right\} \\
& R_{m}^{2}=1-\{(1-0,246)(1-0,050)(1-0,252)\} \\
& R_{m}^{2}=1-(0,754)(0,950)(0,748) \\
& R_{m}^{2}=1-0,5357 \\
& R_{m}^{2}=0,4643
\end{aligned}
$$

The total coefficient of the determinant is 0,4643 , explaining that $46,43 \%$ variance of firm value is determined by variables in the model while remaining $53,57 \%$ is determined by variables outside the model.

Hypothesis Test

Effect of free cash flow on firm value

The result shows that free cash flow has a positive significant effect on firm value so that the first hypothesis is accepted. That effectively means a company with higher free cash flow can survive even in bad condition. This can be a positive signal for investor regarding the prospect of the company in the future. This result accordingly with previous research by Hermuningsih (2016); Al-Zararee \& Al-Azzawi (2016); Ghodrati and Hashemi (2014); and Suartawan \& Yasa (2016), found free cash flow effect was positively regarded the firm value. This research also supports agency theory that explains how management makes a decision to improve the firm value.

\section{Effect of free cash flow on dividend payout}

The result shows that free cash flow has a positive significant effect on dividend payout so that the second hypothesis is accepted. This occurs because the existence of free cash flow encourages shareholder to ask management to use free cash flow for paying a dividend to improve the shareholder's wealth. If free cash flow tended to increase, the opportunity of the dividend payment will increase. This research supports the previous research that free cash flow effect is positive on dividend policy. It is proxied by dividend payout ratio (Mancinelli \& Ozkan, 2006; Kouki \& Guzani, 2009; Rosdini, 2009; Thanatawee, 2011; Lucyanda \& Lilyana, 2012; Arfan \& Maywindlan, 2013; Efni, 2013). Free cash flow effect on the investment opportunity set

The result shows free cash flow mastering negative significant effect regarded the investment opportunity set so that the third hypothesis is rejected. In this study, if free cash flow raises, the ratio of Capital Expenditure to Book Value Asset (CAPBVA) which is the proxy of investment opportunity set will decrease. It occurs because free cash flow that available in company prefer used to pay a dividend, so the free cash flow that available for investing will decrease. This can explain with agency theory that agent and principle have a different interest to use free cash flow. Principle more interests when free cash flow used to pay dividend than take investment opportunity.

\section{Effect of dividend payout on firm value}

The result shows that dividend payout has a positive significant effect on firm value so that the fourth hypothesis is accepted. This relation shows a dividend policy taken by management can increase firm value. The number of dividends which distributes to shareholder act as a positive signal about the capability of the company to increase shareholder's wealth. This study in line with previous research of Fenandar (2012); Rizqia et al., (2013); Febriana et al., (2016); Sedana (2016); Senata (2016); and Esana \& Darmawan (2017), that found dividend payout ratio has a positive effect on firm value. This consist of agency theory and birth in the hand theory which explains investors prefer to get a return as a dividend than the capital gain to increase their wealth. 
Effect of the investment opportunity set on firm value

The result shows that the investment opportunity set has a positive significant effect on firm value so that the fifth hypothesis is accepted. The meaning of this result is decisions which management took about investment opportunity is very important because directly related to the aims of the company. The capability of the company in funding the opportunity set is act as a positive signal for the investor, so that the firm value that proxied by price to book value can increase. This study in line with previous research of Rizqia et al., (2013) and Suartawan \& Yasa (2016), that found it has a positive effect on firm value. Agency theory can explain this relation because the different interest between management and principle can handle with the capability of management to increase firm value.

\section{Free cash flow effect on firm value with dividend payout as a mediator}

The result shows that dividend payout is able to mediate free cash flow effect on firm value so that the sixth hypothesis is accepted. The ability of dividend payout as mediator shows the higher free cash flow will encourage shareholder to tend management for distributing dividends. The amount of dividend payment can influence investors to invest in the company, so the stock price can increase. Aftereffect, firm value will arise.

Free cash flow effect on firm value with a set of investment opportunity

The result shows that the investment opportunity set is unable to mediate the free cash flow effect on firm value so that the seventh hypothesis is rejected. Unableness of investment opportunity as a mediator, because management's decision in using free cash flow for taking investment opportunity set can't increase firm value. Shareholder or investors prefer free cash flow is used to pay dividends to the shareholder's wealth can increase. Furthermore, dividend payout is able to mediate free cash flow effect on firm value, however, investment opportunity unable to mediate it.

\section{Conclusion}

The result of this study are free cash flow has a positive significant effect on firm value and dividend payout, meanwhile has a negative significant effect on investment opportunity set. Then, dividend payout and investment opportunity set included mastering positive significantly effect regarded firm value.

Conflict of interest statement and finding sources

The authors declared that there's no competing interest. The study was financed by personal funding.

\section{Statement of authorship}

The authors have a responsibility for the conception and design of the study. The authors have approved the final article.

Acknowledgments

Authors would like to acknowledge to the editor of IRJMIS for their valuable time, support, and advice to improve the value of this article until publish.

Dewi, I. A. M. C., Sari, M. M. R., Budiasih, I., \& Suprasto, H. B. (2019). Free cash flow effect towards firm value. International Research Journal of Management, IT and Social Sciences, 6(3), 108-116. https://doi.org/10.21744/irjmis.v6n3.643 


\section{References}

Al Zararee, A. N., \& Al-Azzawi, A. (2014). The impact of free cash flow on market value of firm. Global Review of Accounting and Finance, 5(2), 56-63.

Arfan, M., \& Maywindlan, T. (2013). Pengaruh Arus Kas Bebas, Collateralizable Assets, dan Kebijakan Utang Terhadap Kebijakan Dividen Pada Perusahaan Yang Terdaftar Di Jakarta Islamic Index. Jurnal Telaah dan Riset Akuntansi, 6(2), 194-208.

Brigham, E. F., Ehrhardt, M. C., Nason, R. R., \& Gessaroli, J. (2016). Financial Managment: Theory And Practice, Canadian Edition. Nelson Education.

Efni, Y. (2011). Analisis Kebijakan Pendanaan, Kepemilikan Manajerial dan Aliran Kas Bebas terhadap Kebijakan Dividen Pada Perusahaan Non Manufaktur yang Terdaftar di Bursa Efek Indonesia (BEI). Jurnal Ekonomi, 19(01).

Embara, C. T. D. L. (2012). Variabel-Variabel Yang Berpengaruh Terhadap Kebijakan Dividen Serta Harga Saham Pada Perusahaan Manufaktur Di Bursa Efek Indonesia. Matrik: Jurnal Manajemen, Strategi Bisnis dan Kewirausahaan.

Esana, R., \& Darmawan, A. (2017). Pengaruh Kebijakan Dividen dan Keputusan Investasi terhadap Nilai Perusahaan Serta Dampaknya terhadap Profitabilitas T+ 1 (Studi pada Sub Sektor Industri Barang Konsumsi yang Terdaftar di Bei Periode 2006-2016). Jurnal Administrasi Bisnis, 50(6), 201-210.

Fama, E. F., \& French, K. R. (1998). Taxes, financing decisions, and firm value. The Journal of Finance, 53(3), 819843. https://doi.org/10.1111/0022-1082.00036

Febriana, E., \& Djawahir, A. H. (2016). Pengaruh Struktur Modal, Kebijakan Dividen, Ukuran Perusahaan, Kepemilikan Saham Manajerial dan Profitabilitas Terhadap Nilai Perusahaan (Studi pada Perusahaan Manufaktur yang Terdaftar di BEI Pada 2011-2013). Ekonomi Bisnis, 21(2), 163-178.

Fenandar, G. I., \& Raharja, S. (2012). Pengaruh keputusan investasi, keputusan pendanaan, dan kebijakan dividen terhadap nilai perusahaan (Doctoral dissertation, Fakultas Ekonomika dan Bisnis).

Ghodrati, H., \& Hashemi, A. (2014). A study on relationship among free cash flow, firm value and investors' cautiousness: Evidence from Tehran Stock Exchange. Management Science Letters, 4(9), 2001-2010.

Gordon, M. J. (1963). Optimal investment and financing policy. The Journal of finance, 18(2), $264-272$. https://doi.org/10.2307/2977907

Hermuningsih, S. (2012). Pengaruh profitabilitas, size terhadap nilai perusahaan dengan sruktur modal sebagai variabel intervening. Jurnal Fakultas Hukum UII, 16(2).

Jensen, M. C., \& Meckling, W. H. (1976). Theory of the firm: Managerial behavior, agency costs and ownership structure. Journal of financial economics, 3(4), 305-360. https://doi.org/10.1016/0304-405X(76)90026-X

Kouki, M., \& Guizani, M. (2009). Ownership structure and dividend policy evidence from the Tunisian stock market. European Journal of Scientific Research, 25(1), 42-53.

Kouki, M., \& Guizani, M. (2009). Ownership structure and dividend policy evidence from the Tunisian stock market. European Journal of Scientific Research, 25(1), 42-53.

Kusumajaya, D. K. O. (2011). Pengaruh struktur modal dan pertumbuhan perusahaan terhadap profitabilitas dan nilai perusahaan pada perusahaan manufaktur di bursa efek Indonesia. Universitas Udayana, Denpasar: Tesis yang Tidak Dipublikasikan.

Lucyanda, J. (2012). Pengaruh Free Cash Flow dan Struktur Kempemilikan Terhadap Dividend Payout Ratio. Jurnal Dinamika Akuntansi, 4(2). https://doi.org/10.15294/jda.v4i2.2171

Myers, S. C. (1977). Determinants of corporate borrowing. Journal of financial economics, 5(2), $147-175$. https://doi.org/10.1016/0304-405X(77)90015-0

Naini, W. D., \& Ismiwatis, D. (2014). Pengaruh Free Cash Flow Dan Kepemilikan Institusional Terhadap Kebijakan Hutang Dan Nilai Perusahaan. Jurnal Ilmu Dan Riset Akuntansi, 3(4), 1-17.

Nuryani, N. N. J., Satrawan, D. P. R., Gorda, A. A. N. O. S., \& Martini, L. K. B. (2018). Influence of human capital, social capital, economic capital towards financial performance \& corporate social responsibility. International Journal of Social Sciences and Humanities, 2(2), 65-76. https://doi.org/10.29332/ijssh.v2n2.128

Ogunsiji, A., \& Ladanu, W. (2017). A theoretical study of performance measures in the strategic and corporate entrepreneurships of firms. International Journal of Physical Sciences and Engineering, 1(1), 72-80. https://doi.org/10.21744/ijpse.v1i1.15

Rizqia, D. A., \& Sumiati, S. A. (2013). Effect of Managerial Ownership, Financial Leverage, Profitability, Firm Size, and Investment Opportunity on Dividend Policy and Firm Value. Research Journal of Finance and Accounting, 4(11), 120-130.

Rosdini, D. (2009). Pengaruh free cash flow terhadap Dividend Payout Ratio. Department of accounting. Universitas 
Padjajaran. Bandung.

Senata, M. (2016). Pengaruh Kebijakan Dividen terhadap Nilai Perusahaan yang tercatat pada Indeks LQ-45 Bursa Efek Indonesia. Jurnal Wira Ekonomi Mikroskil: JWEM, 6(1), 73-84.

Suartawan, I. G. N. P. A., \& Yasa, G. W. (2016). Pengaruh Investment Opportunity Set dan Free Cash Flow Pada Kebijakan Dividen dan Nilai Perusahaan. E-Jurnal Akuntansi, 2014-2044.

Suherli, M., \& Harahap, S. S. (2007). Studi Empiris Terhadap Faktor Penentu Kebijakan Jumlah Dividen. Media Riset Akuntansi, Auditing \& Informasi, 4(3), 223-245.

Thanatawee, Y. (2011). Life-cycle theory and free cash flow hypothesis: Evidence from dividend policy in Thailand. International Journal of Financial Research, 2(2).

Wijaya, B. I., \& Sedana, I. B. (2015). Pengaruh profitabilitas terhadap nilai perusahaan (kebijakan dividen dan kesempatan investasi sebagai variabel mediasi). E-Jurnal Manajemen Universitas Udayana, 4, 12.

Dewi, I. A. M. C., Sari, M. M. R., Budiasih, I., \& Suprasto, H. B. (2019). Free cash flow effect towards firm value. International Research Journal of Management, IT and Social Sciences, 6(3), 108-116. https://doi.org/10.21744/irjmis.v6n3.643 


\section{Biography of Authors}

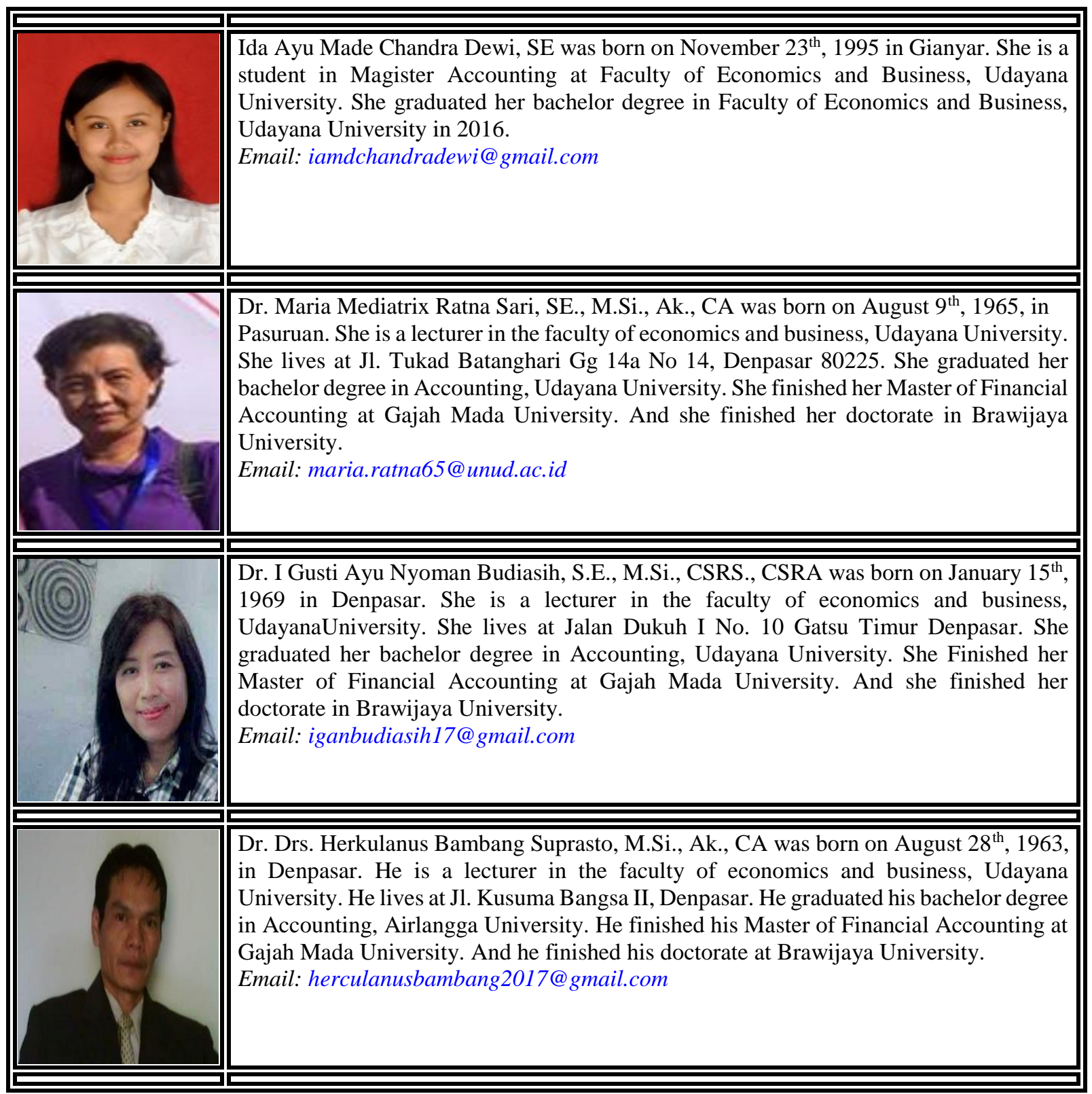

